UDC 616-056.7-07

doi: http://dx.doi.org/10.15407/ubj88.01.069

\title{
CHITOTRIOSIDASE ACTIVITY AS ADDITIONAL BIOMARKER IN THE DIAGNOSIS OF LYSOSOMAL STORAGE DISEASES
}

\author{
N. V. OLKHOVYCH
}

State Institute of Genetic and Regenerative Medicine of NAMS of Ukraine, Kyiv; National Children's Hospital “OHMATDYT”, Ministry of Health of Ukraine, Kyiv; e-mail: nolhovich@gmail.com

To date, several genetic variants that lead to a deficiency of chitotriosidase activity have been described. The duplication of $24 \mathrm{bp}$ (dup24bp) in exon 10 of the CHIT1 gene, which causes a complete loss of enzymatic activity of the gene product, is the most common among the European population. The aim of the study was to evaluate the possibility of using chitotriosidase activity as an additional biomarker in diagnosis of lysosomal storage diseases (LSDS) in Ukraine, to determine this parameter in blood plasma of the patients with various lysosomal diseases and to assess the effect of the presence of dup24bp in the CHIT1 gene on this parameter. It has been shown that chitotriosidase activity in blood plasma is a convenient additional biochemical marker in the diagnosis of some LSDs, namely Gaucher disease, Niemann-Pick disease A, B, C and GM1-gangliosidosis. Reference ranges of the normal chitotriosidase activity were determined in blood plasma of Ukrainian population and found to be 8.0-53.1 nmol 4-methylumbelliferone/h.ml of plasma. The total allele frequency of the dup24bp in the CHIT1 gene in Ukrainian population was determined, which amounted to 0.26 (323/1244) that is higher than in European population. It was indicated that moleculargenetic screening of dup24bp in the CHIT1 gene is a necessary stage in a protocol for the laboratory diagnosis of Gaucher disease, Niemann-Pick disease A, B, C as well as GM1-gangliosidosis to avoid incorrect diagnosis.

Key word s: chitotriosidase, lysosomal storage diseases, deficiency in chitotriosidase activity, CHITl gene.

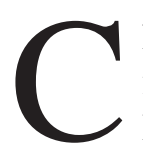

hitinases (3.2.1.14) are enzymes, the main function of which is to degrade chitin. Mammalian chitinases belong to the glycosyl hydrolase 18 family (GH-18) and are characterized by both endochitinase activity (that is, they cleave randomly chitin polymer into oligosaccharides of varying lengths) and exochitinase activity (they cleave off $\mathrm{N}$-acetylglucosamine monosaccharide from the end of chitin polymer) [1]. It is believed that the ability of mammalian chitinases to degrade chitin-containing pathogens such as intracellular parasites, fungi, chitin-containing microorganisms, etc., is their primary biological function. Human chitinase was first discovered owing to its ability to hydrolyze chitotriosidase substrates that determined its name chitotriosidase (CHIT1) [1].

Chitotriosidase gene CHIT1 (OMIM 600031.0001) localized on chromosome 1q32.1 contains 11 exons and spans about 14000 bp of genomic DNA encoding a protein of 466 amino acids [2]. At present, several genetic variants that cause a deficiency in chitotriosidase activity have been described.
Duplication of 24-bp (dup24bp) in exon 10 of the gene (rs3831317) is the most common among the European population [3]. This duplication causes aberrant splicing and a deletion of amino acids 344-372, resulting in a complete loss of enzymatic activity of the gene product. It has been shown that individuals who have a pronounced deficiency in chitotriosidase activity are characterized by increased susceptibility to chitin-containing pathogens such as Wuchereria bancroftifilarial, Plasmodium falciparum malaria, Cryptococcus neoformans and Candida albicans [4].

CHIT1 is mainly produced by activated macrophages [1]. Taking into account that CHIT1 is the most active in macrophages, it has been shown that hyper production of the enzyme occurs upon various chronic inflammatory processes such as atherosclerosis, idiopathic juvenile rheumatoid arthritis, inflammatory intestinal disorders, granulomatous and fibrotic interstitial lung diseases and others [5-8]. A significant increase in chitotriosidase activity is also observed upon some lysosomal storage diseases (LSDs), which are inherited metabolic disorders 
caused by defective functioning of specific lysosomal hydrolases and accompanied by the accumulation of undegraded intracellular metabolites [9].

To date, more than 50 LSDs have been described, which altogether occur with an incidence of about 1:5000 of live births [9]. Despite the differences in nature of the accumulated substances upon different LSDs, there are many common features in the pathogenesis of these diseases [10]. The immune response to chronic accumulation of undegraded substrates leads to the development of chronic inflammation accompanied by the macrophages activation and increased secretion by these cells of large amounts of various inflammatory mediators, including chitotriosidase [11].

Thus, an increase in the chitotriosidase activity upon some LSDs is a secondary biomarker used in a diagnostic protocol, in parallel with detection of the primary biochemical defect, that is, the determination of the activity of the corresponding lysosomal enzyme in the blood cells, as well as for monitoring the efficacy of a specific therapy [12]. However, the presence of dup24bp in the CHIT1 gene of LSDs patients, on the one hand, can complicate the diagnostic process resulting in incorrect diagnosis and, on the other hand, can make it impossible to use chitotriosidase activity as a biomarker for monitoring the efficacy of enzyme replacement therapy. This problem is of particular importance due to rather high frequency of dup24bp in the European population [4, 12-18].

The aim of our study was to evaluate the possibility of using chitotriosidase activity as an additional biomarker for the diagnosis of LSDs in Ukraine by determining this parameter in blood plasma of the patients with various lysosomal diseases and effect of dup24bp in the CHIT1 gene on this parameter.

\section{Materials and Methods}

Plasma and whole peripheral blood of patients with confirmed LSDs (190 persons) and healthy donors (622 persons) with no LSDs were used in the study. The written informed consent was obtained from each participant after the nature of the study had been fully explained. Among the volunteers were representatives from all regions of Ukraine that allowed us to consider the obtained results as a characteristic for the entire population of Ukraine.

Chitotriosidase activity in plasma was evaluated by degradation of the fluorogenic substrate.
As a substrate, $22 \mu \mathrm{M}$ of 4-methylumbelliferonetriacetylchitotriazide (Sigma, USA) in citrate-phosphate buffer ( $\mathrm{pH}$ 5.2) was used. The reaction mixture contained $5 \mu \mathrm{l}$ of plasma and $100 \mu \mathrm{l}$ of substrate. Incubation of samples was carried out at $37^{\circ} \mathrm{C}$ for $1 \mathrm{~h}$. Reaction was terminated by adding $1.0 \mathrm{ml}$ of $0.25 \mathrm{M} \mathrm{NaOH}$-glycine buffer ( $\mathrm{pH}$ 10.4). Calibration was carried out using a series of dilutions of standard $500 \mu \mathrm{M}$ 4-methylumbelliferone (4-MU) solution (Sigma, USA). 4-MU fluorescence was measured at excitation wavelength $365 \mathrm{~nm}$ and emission wavelength $448 \mathrm{~nm}$ with fluorometer Victor (WallacOy). The results were expressed as nmol 4-MU/h $\mathrm{ml}$ of plasma. Samples with chitotriosidase activity more than $100 \mathrm{nmol}$ of $4-\mathrm{MU} / \mathrm{h} \cdot \mathrm{ml}$ plasma were restudied [19]. For this purpose, plasma was 50-fold diluted with $0.2 \%$ human serum albumin (HSA) and incubated with substrate for $15 \mathrm{~min}$.

DNA was isolated from peripheral whole blood obtained with EDTA using DNA-sorb-V kit (Central Research Institute of Epidemiology, $\mathrm{MOH}$, Russia). The quality of DNA samples was evaluated by measuring absorbance at $260 \mathrm{~nm}$ with a spectrophotometer Specord-40 (AnalytikJena AG). DNA samples were stored at $4{ }^{\circ} \mathrm{C}$. Dup24bp in 10 exon of the CHIT1 gene was determined by PCR method as described in [20]. Standard mixture for amplification and primers such as 5'-AGCTATCTGAAGCAGAAG-3' and R 5'-GGAGAAGCCGGCAAAGTC-3' were used for reaction. The amplification conditions were the following: denaturation step for $10 \mathrm{~min}$ at $94{ }^{\circ} \mathrm{C}, 41$ cycles: for $30 \mathrm{sec}$ at $94{ }^{\circ} \mathrm{C}$, for $30 \mathrm{sec}$ at $51{ }^{\circ} \mathrm{C}$, for $30 \mathrm{sec}$ at $72{ }^{\circ} \mathrm{C}$ and prolonged annealing for $5 \mathrm{~min}$ at $72^{\circ} \mathrm{C}$. Such reaction allowed identifying the allele with duplication (fragment $99 \mathrm{bp}$ ), heterozygotes (fragments 75 bp and 99 bp) and wild-type allele (fragment $75 \mathrm{bp}$ ). Visualization was performed in $3 \%$ agarose gel by staining with ethidium bromide.

Statistical analysis of the obtained results on chitotriosidase activity was performed using MS Excel spreadsheets. Normality of the data distribution was assessed by $\chi^{2}$ criterion and KolmogorovSmirnov test. For the patients with Gaucher disease, heterozygous for the duplication, Yates correction was applied due to the smaller amount of data -7 persons. Taking into account that all mentioned parameters had been normally distributed, the standard Student's $t$-test was used to assess the significance of differences between these groups. 


\section{Results and Discussion}

Taking into account the high frequency of dup24bp in the CHIT1 gene in European countries [4, 12-18], its prevalence among the population of Ukraine was assessed by screening of this genetic variant in 622 voluntary donors. In 362 individuals (58.2\%) dup24bp in the CHIT1 gene was not detected; in 197 persons (31.7\%) the duplications were found in the heterozygous state and in 63 persons $(10.1 \%)$ - in the homozygous state. The overall allele frequency of dup24bp in the CHIT1 gene in the population of Ukraine was 0.26 (323/1244).

Thus, considering the high probability of dup24bp in the CHIT1 gene in the population of Ukraine, CHIT1 genotype was determined obligatorily during the further study of chitotriosidase activity in patients with LSDs to avoid the influence of hereditary deficiency on this parameter.

Chitotriosidase activity in healthy individuals with no dup24bp in the CHIT1 gene ranged from 3.3 to $81.0 \mathrm{nmol} 4-\mathrm{MU} / \mathrm{h} \mathrm{ml}$ of plasma; in the patients with one copy of active CHIT1 gene this parameter ranged from 0.9 to $24.3 \mathrm{nmol} 4-\mathrm{MU} / \mathrm{h} \mathrm{ml}$ of plasma, and in the patients with genotype dup24bp/ dup24bp - from 0 to $1.3 \mathrm{nmol} 4-\mathrm{MU} / \mathrm{h} \cdot \mathrm{ml}$ of plasma (Fig. 1). Data analysis of chitotriosidase activity in healthy individuals considering their genotype showed that the average activity of the enzyme in homozygotes for the wild-type allele (allele $\mathrm{N}$ ) CHIT1 gene reliably differ from the activity of the enzyme in homozygotes for dup24bp and heterozygote carriers of this duplication $(P<0.05)$.

Thus, analyzing chitotriosidase activity in blood plasma of the LSDs patients, it was assumed that the increased activity was the activity, which exceeded $53 \mathrm{nmol} 4-\mathrm{MU} / \mathrm{h} \cdot \mathrm{ml}$ of plasma in case of the absence of dup24bp in the CHIT1 gene $\left(95^{\text {th }}\right.$ percentile).

Assessment of chitotriosidase activity in the blood plasma of the patients from Ukraine with confirmed clinically and biochemically LSDs was carried out (Table 1). A nosological diagnosis of LSDs was based on the evaluating of the primary biochemical defect, namely, the deficiency of activity of the corresponding lysosomal enzyme in leukocyte homogenates. Taking into account the abundance of deficient variant of the CHIT1 gene in Ukrainian

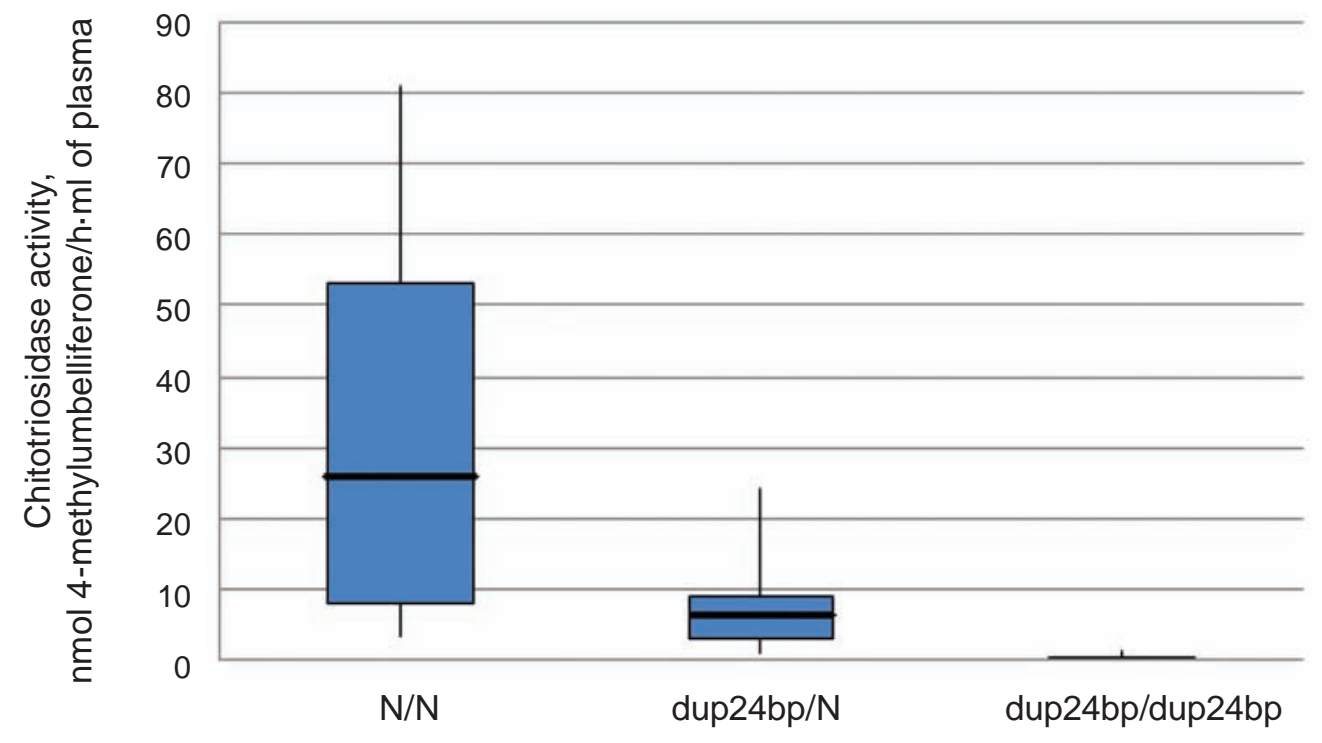

\begin{tabular}{|l|c|c|c|}
\hline Average value $( \pm$ SD) & $26.1 \pm 13.7$ & $6.9 \pm 3.1$ & $0.59 \pm 0.23$ \\
\hline Maximal value & 81 & 24.3 & 1.31 \\
\hline Minimal value & 3.3 & 0.9 & 0 \\
\hline Reference range (5-95\%) & $8.0-53.1$ & $3.5-9.1$ & $0-0.49$ \\
\hline Number of persons & 362 & 197 & 63 \\
\hline
\end{tabular}

Fig. 1. Distribution of the values of chitotriosidase activity in blood plasma of healthy individuals accordingly to the CHIT1-genotype: $N / N$ - homozygous for the wild-type allele; dup $24 b p / N$ - heterozygote carriers of duplication; dup24bp/dup24bp - homozygous for duplication 
Ta b le 1. Chitotriosidase activity in the blood plasma of patients with LSDs

\begin{tabular}{|c|c|c|c|}
\hline Disease & $\begin{array}{l}\text { Number } \\
\text { of examined } \\
\text { patients }\end{array}$ & $\begin{array}{l}\text { Number of patients } \\
\text { with increased } \\
\text { chitotriosidase } \\
\text { activity }\end{array}$ & $\begin{array}{c}\text { Chitotriosidase activity, } \\
\text { nmol } 4-\mathrm{MU} / \mathrm{h} \cdot \mathrm{ml} \\
\text { of plasma }\end{array}$ \\
\hline \multicolumn{4}{|l|}{ Mucopolysaccharidoses } \\
\hline MPS I (Hurler-Scheie syndrome) & 7 & 0 & $5-40$ \\
\hline MPS II (Hunter syndrome) & 13 & 0 & $12-34$ \\
\hline MPS III A (Sanfilippo syndrome A) & 9 & 0 & $2-45$ \\
\hline MPS III B (Sanfilippo syndrome B) & 2 & 0 & 3,54 \\
\hline MPS III C (Sanfilippo syndrome C) & 1 & 0 & 13 \\
\hline MPS IV A (Morquio syndrome A) & 12 & 0 & $3-62$ \\
\hline MPS IV B (Morquio syndrome B) & 1 & 0 & 7 \\
\hline MPS VI (Marteaux-Lamy syndrome) & 2 & 0 & 9,13 \\
\hline \multicolumn{4}{|l|}{ Sphingolipidoses } \\
\hline Metachromatic leukodystrophy & 15 & 0 & $2-44$ \\
\hline GM1 gangliosidose & 17 & 15 & $01 *, 442-3094$ \\
\hline Gaucher disease & 56 & 53 & $0 *, 3182-33238$ \\
\hline Fabry disease & 3 & 0 & 3-15 \\
\hline Krabbe disease & 8 & 2 & $5-5,120,290$ \\
\hline GM2 gangliosidose & 4 & 0 & 8-25 \\
\hline Niemann-Pick disease A/B & 6 & 6 & $658-2506$ \\
\hline Niemann-Pick disease C & 2 & 2 & 1433, 1675 \\
\hline \multicolumn{4}{|l|}{ Mucolipidoses } \\
\hline Mucolipidose II & 6 & 0 & $4-31$ \\
\hline Mucolipidose III & 2 & 0 & 3,14 \\
\hline \multicolumn{4}{|l|}{ Oligosaccharidoses } \\
\hline$\alpha$-mannosidosis & 2 & 0 & 11,16 \\
\hline Fucosidosis & 1 & 0 & 24 \\
\hline Sialidosis & 1 & 0 & 12 \\
\hline Galactosialidosis & 1 & 0 & 9 \\
\hline \multicolumn{4}{|l|}{ Other LSDs } \\
\hline Neuronal ceroid lipofuscinosis II & 7 & 0 & $1-55$ \\
\hline Pompe disease & 3 & 0 & $6-22$ \\
\hline Control & 622 & & $0-81$ \\
\hline
\end{tabular}

* Chitotriosidase activity in the patients who have homozygous dup24bp.

population, a genotype for that gene was also determined in all patients with LSDs to avoid the influence of hereditary deficiency of chitotriosidase activity on the results.
It should be noted that there was no increase in chitotriosidase activity in the patients with mucopolysaccharidosis, oligossaccharidosis and mucolipidosis upon confirmed absence of dup24bp in 
the CHIT1 gene. There was also no increase in the activity in the patients with type II ceroid lipofuscinosis and Pompe disease.

The largest increase in chitotriosidase activity in plasma was observed in the patients with Gaucher disease. This feature has been well described and widely used as an additional biomarker in diagnostics of the disease and in monitoring the efficacy of specific therapy [12]. In the examined patients with Gaucher disease, chitotriosidase activity in plasma exceeded the average values by 100-400-fold compared to healthy persons, that is significantly higher than at any other LSDs. However, hereditary deficiency of chitotriosidase activity should be taken into account in case of application of this biomarker for primary diagnosis of Gaucher diseases.

It can be seen (Fig. 2) that among the examined 56 patients with Gaucher disease, complete absence of chitotriosidase activity has been observed in three persons owing to deficient variant of the CHIT1 gene, and in the patients with dup24bp in heterozygous state, chitotriosidase activity reliably differed from the activity in homozygote wild-type allele
$(P<0.05)$. The total allele frequency of dup24bp in the CHIT1 gene in the patients with Gaucher disease in Ukraine was 0.12 (13/112).

Taking into account that a significant increase in chitotriosidase activity is an additional specific diagnostic marker of this disease, along with the primary biochemical defect (leukocyte glucocerebrosidase deficiency), the absence of this activity can lead to misinterpretation of the biochemical data and false-negative diagnosis of Gaucher disease.

Besides the patients with Gaucher disease, all patients with Niemen-Pick disease A/B and C as well as majority of the patients with GM1-gangliosidosis also had an increased chitotriosidase activity, although not as significant as in case of Gaucher disease (Fig. 3). Two patients with GM1-gangliosidosis, who did not have an increased chitotriosidase activity, had dup24bp in both alleles of the CHIT1 gene, i.e. a hereditary deficiency of this enzyme.

It should be noted that the average values of chitotriosidase activity in the patients with Gaucher disease, GM1-gangliosidosis, Niemen-Pick disease $\mathrm{A} / \mathrm{B}$ and $\mathrm{C}$, and with confirmed absence of dup24bp

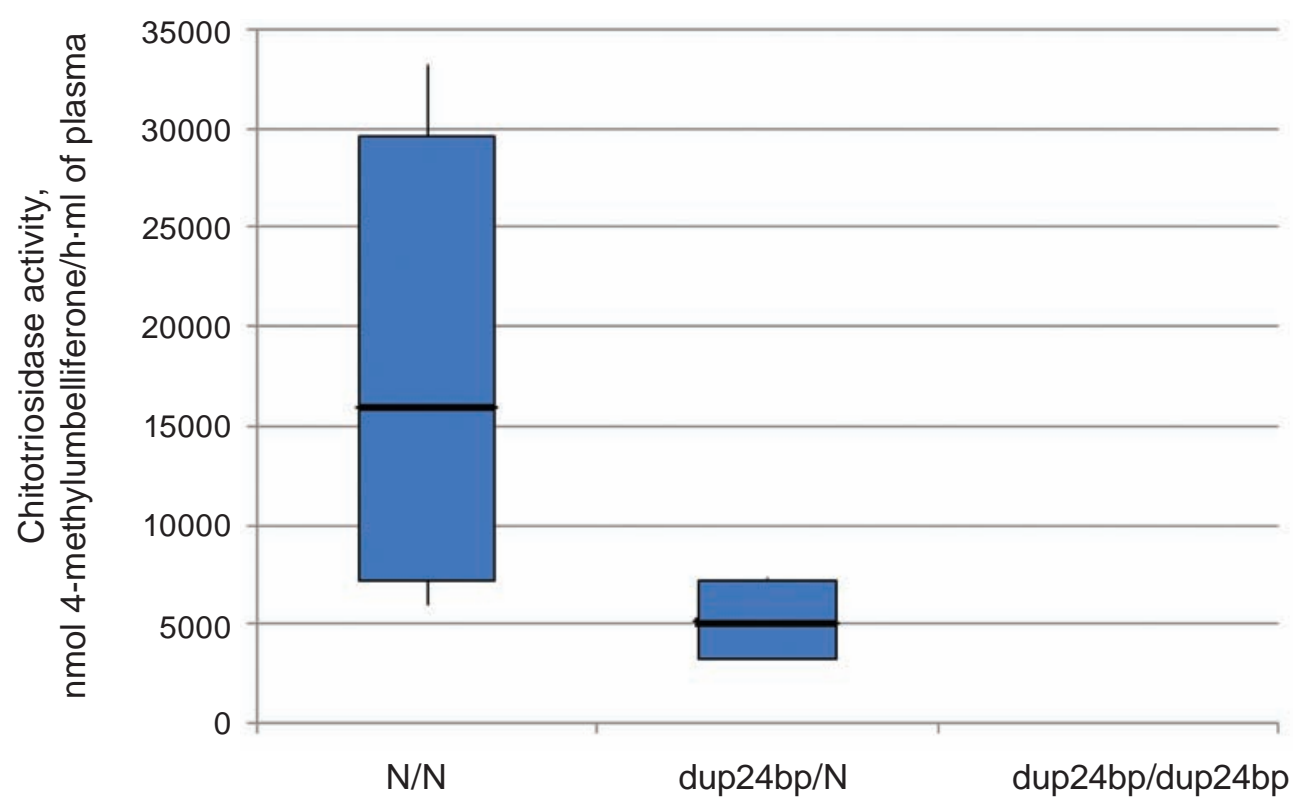

\begin{tabular}{|l|c|c|c|}
\hline Average value $( \pm$ SD) & $16509 \pm 7738$ & $5016 \pm 1684$ & 0 \\
\hline Maximal value & 33238 & 7293 & 0 \\
\hline Minimal value & 6011 & 3182 & 0 \\
\hline Reference range (5-95\%) & $7172-29614$ & $3229-7111$ & 3 \\
\hline Number of persons & 46 & 7 & \\
\hline
\end{tabular}

Fig. 2. Distribution of the values of chitotriasidase activity in blood plasma of the patients with type 1 Goucher disease accordingly to the CHIT1-genotype: N/N - homozygous for wild-type allele; dup $24 \mathrm{bp} / \mathrm{N}$ - heterozygote carrier of duplication; dup24bp/dup24bp - homozygous for duplication 
significantly differ from the values of chitotriosidase activity in healthy individuals $(P<0.05)$. Reference ranges of the activity in these groups of patients did not overlap with ranges in the controls, except the patients with Krabbe disease. A slight increase in chitotriosidase activity was found only in two of eight patients with Krabbe disease, whilst the remaining six patients had a normal activity of chitotriosidase upon confirmed absence of dup24bp in the CHIT1 gene. This led to a disruption of the normal distribution and to the absence of reliable differences between the values obtained for this group of patients and a control group of healthy individuals $(P>0.05)$.
Thus, the use of this feature as an additional diagnostic biomarker for the diagnosis of Krabbe disease is considered to be inappropriate.

Thus, chitotriosidase activity in plasma can serve as an additional convenient biomarker in the diagnostics of mentioned above LSDs in Ukraine on condition of obligatory test of the absence of hereditary deficiency of this enzyme.

The LSDs pathogenesis is based on the accumulation of undegraded components in cells that leads to the development of a chronic inflammation as a result of activation of the immune system [11]. According to modern concepts, the LSDs pathogene-

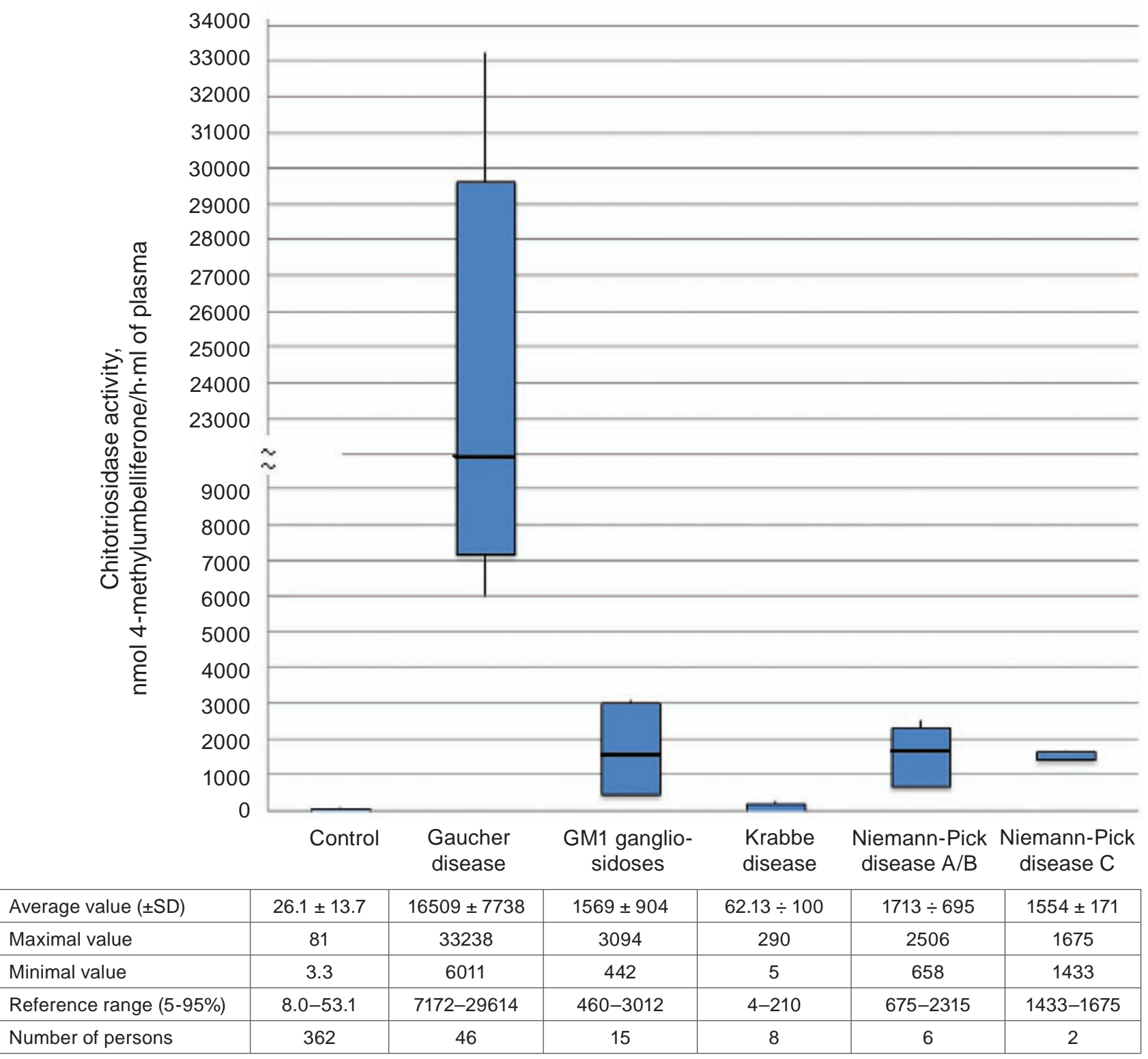

Fig. 3. Distribution of the values of chitotriosidase activity in blood plasma of the patients with LSDs who have no dup24bp in the CHIT1 gene 
sis is a cascade of biochemical and cellular reactions in response to an intracellular accumulation of undegraded substrates. The contribution of different reactions to the development of the pathological process upon various LSDs differs greatly and depends on the type and toxicity of the accumulated substrate [10]. A common feature of the diseases, for which an increased chitotriosidase activity in blood plasma has been shown, is the defective macrophage function and tissue infiltration by macrophages resulting in the visceral organs failure.

Thus, an increased chitotriosidase activity has been found to be a result of a pathological process induced by accumulation of undegraded substrate in activated macrophages, so this marker can be an indicative feature of the severity of the pathological process in patient. These data resulted in the recommendations of the International Collaborative Gaucher Group (ICGG) on the use of chitotriosidase activity in blood plasma as a biomarker for the identifying of the patients with Gaucher disease and monitoring the efficacy of enzyme replacement therapy [12]. However, genetic variations in the CHIT1 gene, which significantly affect the activity of the enzyme, complicate the diagnosis of Gaucher disease and other LSDs and make it impossible to use this biomarker for monitoring of the patients carriers of these genetic variants.

In our study the frequency of dup24bp in the CHIT1 gene, which significantly affect the chitotriosidase activity, has been analyzed. It has been shown that the obtained frequency of homozygotes upon dup24bp in the CHIT1 gene in the Ukrainian population was higher than the frequency of this genetic variant in other European populations (Table 2).

It is known that genetic drift is the main factor causing fluctuation of allelic distribution [16]. This occurs in a random manner however it may lead to the removal of mutant genotypes from the population during an uncertain period of time. In small and limited populations, this process occurs faster, since each random event affects the overall allele distribution more significantly. Therefore, it is possible that in African and other populations the mutant CHIT1 genotype has been lost during this process. Furthermore, genetic drift in West Africa can be enhanced by migration of African population to Europe and Asia. [16] Other researchers suggested that the low allele frequency of dup24bp in some regions is associated with a high prevalence of parasitic diseases and other chitin-containing pathogens responsible

Ta ble 2. Genotype frequencies for dup 24bp allele in the CHIT1 gene for various populations

\begin{tabular}{l|c|c|c|c}
\hline \multicolumn{1}{c|}{ Population } & $\begin{array}{c}\text { Number } \\
\text { of examined } \\
\text { persons }\end{array}$ & $\begin{array}{c}\text { Heterozygote } \\
\text { frequency } \\
\text { (dup24bp/N), \% }\end{array}$ & $\begin{array}{c}\text { Homozygote } \\
\text { frequency } \\
\text { (dup24bp/dup24bp), \% }\end{array}$ & Reference \\
\hline Africa & 492 & $0-0.2$ & 0 & {$[4]$} \\
Morocco & 90 & 20 & 0 & {$[16]$} \\
Italy (continental) & 99 & 34.3 & 2.0 & {$[16]$} \\
Portugal & 295 & 37.3 & 2.7 & {$[18]$} \\
Spain & 269 & 36.8 & 3.7 & {$[12]$} \\
Turkey & 95 & 29.5 & 4.2 & {$[16]$} \\
Netherland & 171 & 35.1 & 6.4 & {$[3]$} \\
Brazil & 122 & 42.6 & 9.0 & {$[17]$} \\
France (continental) & 128 & 31.3 & 9.3 & This study \\
Ukraine & 622 & 31.7 & 10.1 & {$[13]$} \\
Mexican & 692 & 44.2 & 11.3 & {$[14]$} \\
Amerindians & 135 & $30-56$ & $12-26$ & {$[15]$} \\
Peruvian & & & & \\
Amerindians & 231 & 47.2 & 32.5 & \\
Korea & & & & \\
\hline
\end{tabular}


for the presence of population selection for this variant of the CHIT1 gene. High level of parasite invasion in African population and selection towards the need for high chitotriosidase activity explains an almost complete absence of duplication in the CHIT1 gene in the population of this continent [4]. Further researches on the cause of the high frequency of hereditary deficiency of chitotriosidase activity among the population of Ukraine are required.

Thus, the high frequency of dup24bp in the CHIT1 gene among the population of Ukraine makes the screening of this genetic variant an important stage of the diagnostic protocol to identify patients with LSDs. Furthermore, it should be noted that $4.6 \%$ of the patients with Gaucher disease in Ukraine have a hereditary deficiency of chitotriosidase activity, which makes it impossible to use this biomarker to monitor the efficacy of enzyme replacement therapy in these patients and requires the use of other indicators.

Thus, the obtained data enable us to draw some conclusions, namely:

- chitotriosidase activity in blood plasma is a convenient additional biochemical marker in the diagnosis of some LSDs, such as Gaucher disease, Niemann-Pick disease A/B and C, GM1-gangliosidosis;

- reference intervals of normal chitotriosidase activity in the blood plasma of the population of Ukraine ranged from 8.1 to $53.1 \mathrm{nmol} 4-\mathrm{MU} / \mathrm{h} \cdot \mathrm{ml}$ of plasma;

- total allele frequency of dup24bp in the CHIT1 gene among the population of Ukraine was $0.26(323 / 1244)$ that is higher than the frequency of this genetic variant in other European populations; the total frequency of the allele dup24bp in the CHIT1 gene in the patients with Gaucher disease from Ukraine was 0.12 (13/112);

- molecular-genetic screening of dup24bp in the CHIT1 gene is a necessary step in the laboratory diagnosis of Gaucher disease, Niemann-Pick disease $\mathrm{A} / \mathrm{B}, \mathrm{C}$ and GM1-gangliosidosis to avoid an incorrect diagnosis of these diseases in Ukraine;

- for the patients with Gaucher disease who have dup24bp in the CHIT1 gene, the use of other biomarkers to monitor the efficacy of enzyme replacement therapy is required.

\section{ХІТОТРІОЗИДАЗНА АКТИВНІСТЬ ЯК ДОДАТКОВИЙ БІОМАРКЕР У ДІАГНОСТИЦІ ЛІЗОСОМНИХ ХВОРОБ НАКОПИЧЕННЯ}

\section{Н. В. Ольхович}
ДУ Інститут генетичної та регенеративної медицини НАМН України, Київ;
НДСЛ «ОХМАТДИТ» МОЗ України, Київ; e-mail: nolhovich@gmail.com

Описано кілька генетичних варіантів, що призводять до дефіциту хітотріозидазної активності, але найрозповсюдженішим серед європейських популяцій $є$ дуплікація 24 п.н. (dup24bp) в 10-му екзоні гена CHIT1, яка спричинюе повну втрату ензиматичної активності продукту гена. Метою роботи було оцінити можливість використання хітотріозидазної активності як додаткового біомаркера в діагностиці лізосомних хвороб накопичення (ЛХН) в Україні, визначити цей показник у плазмі крові пацієнтів із різними лізосомними захворюваннями та оцінити вплив на нього наявності dup24bp в гені СНIT. Показано, що хітотріозидазна активність плазми крові $\epsilon$ зручним додатковим біохімічним маркером у комплексній діагностиці окремих ЛХН, а саме хвороби Гоше, хвороби Німанна-Піка А,В,C та GM1-гангліозидозу. Визначено референсні межі нормальної хітотріозидазної активності в плазмі крові населення України, які становлять 8,053,1 нмоль 4-метилумбеліферону/год·мл плазми, у той саме час сумарна частота алеля dup24bp в гені СНIT1 становить 0,26 (323/1244), що вище за частоту цього генетичного варіанта в інших європейських популяціях. Зазначено, що молекулярно-генетичний скринінг dup24bp в гені CHIT1 є необхідним етапом протоколу лабораторного діагностування хвороби Гоше, хвороби Німанна-Піка А,B,C та GM1-гангліозидозу для уникнення хибної діагностики цих захворювань.

К л ю чо в і с лова: хітотріозидаза, лізосомні хвороби накопичення, дефіцит хітотріозидазної активності, ген CHIT1. 


\section{ХИТОТРИОЗИДАЗНАЯ АКТИВНОСТЬ КАК ДОПОЛНИТЕЛЬНЫЙ БИОМАРКЕР В ДИАГНОСТИКЕ ЛИЗОСОМНЫХ БОЛЕЗНЕЙ НАКОПЛЕНИЯ}

\section{Н. В. Ольхович}

\author{
ГУ Институт генетической и регенеративной \\ медицины НАМН Украины, Киев; \\ НДСБ «ОХМАТДЕТ» МЗ Украины, Киев; \\ e-mail: nolhovich@gmail.com
}

Описано несколько генетических вариантов, приводящих к дефициту хитотриозидазной активности, хотя наиболее распространенным среди европейских популяций является дупликация 24 п.н. (dup 24 bp) в 10-ом экзоне гена CHIT1, которая приводит к полной потеpe энзиматической активности продукта гена. Целью работы было оценить возможность использования хитотриозидазной активности в качестве дополнительного биомаркера в диагностике лизосомных болезней накопления (ЛБН) в Украине путем определения этого показателя в плазме крови пациентов с различными лизосомными заболеваниями и влияния на него наличия dup24bp в гене CHIT1. Показано, что хитотриозидазная активность в плазме крови является удобным дополнительным биохимическим маркером в комплексной диагностике отдельных ЛБН - болезни Гоше, болезни Ниманна-Пика А, B, C и GM1-ганглиозидоза. Определены референсные пределы нормальной хитотриозидазной активности в плазме крови населения Украины, которые составляют 8,053,1 нмоль 4-метилумбелиферона/ч·мл плазмы, в то же время суммарная частота аллеля dup24bp в гене CHIT1 равна 0,26 (323/1244), что выше частоты этого генетического варианта в других европейских популяциях. Отмечено, что молекулярно-генетический скрининг dup24bp в гене CHIT1 является необходимым этапом протокола лабораторного диагностирования болезни Гоше, болезни Ниманна-Пика А, B, C и GM1ганглиозидоза во избежание ложной диагностики этих заболеваний.

К л юче вы е с лов а: хитотриозидаза, лизосомные болезни накопления, дефицит хитотриозидазной активности, ген СНIT1.

\section{References}

1. Kanneganti M., Kamba A., Mizoguchi E. Role of chitotriosidase (chitinase 1) under normal and disease conditions. J. Epithel. Biol. Pharmacol. 2012; 5(1): 1-9.

2. Eiberg H., Den Tandt W. R. Assignment of human plasma methylumbelliferyl-tetra-Nacetylchitotetraoside hydrolase or chitinase to chromosome 1q by a linkage study. Hum. Genet. 1997; 101(2): 205-207.

3. Boot R. G., Renkema G. H., Verhoek M., Strijland A., Bliek J., de Meulemeester T. M., Mannens M. M., Aerts J. M. The human chitotriosidase gene. Nature of inherited enzyme deficiency. J. Biol. Chem. 1998; 273(40): 2568025685.

4. Arndt S., Hobbs A., Sinclaire I., Lane A. B. Chitotriosidase deficiency: a mutation update in an african population. JIMD Rep. 2013; 10: 11-16.

5. Sutherland T. E., Maizels R. M., Allen J. E. Chitinases and chitinase-like proteins: potential therapeutic targets for the treatment of T-helper type 2 allergies. Clin. Exp. Allergy. 2009; 39(7): 943-955.

6. Artieda M., Cenarro A., Gañán A., Jericó I., Gonzalvo C., Casado J. M., Vitoria I., Puzo J., Pocoví M., Civeira F. Serum chitotriosidase activity is increased in subjects with atherosclerosis disease. Arterioscler. Thromb. Vasc. Biol. 2003; 23(9): 1645-1652.

7. Malaguarnera L., Di Rosa M., Zambito A. M., dell'Ombra N., Nicoletti F., Malaguarnera M. Chitotriosidase gene expression in Kupffer cells from patients with non-alcoholic fatty liver disease. Gut. 2006; 55(9): 1313-1320.

8. Shuhui L., Mok Y. K., Wong W. S. Role of mammalian chitinases in asthma. Int. Arch. Allergy Immunol. 2009; 149(4): 369-377.

9. Mehta A., Winchester B. Lysosomal storage disorders: a practical guide. London: WileyBlackwell, 2012. P. 37-46.

10. Vitner E. B., Platt F. M., Futerman A. H. Common and Uncommon Pathogenic Cascades in Lysosomal Storage Diseases. J. Biol. Chem. 2010; 285(27): 20423-20427.

11. Cotran R. S., Kumar V., Robbins S. L., Schoen F. J. (eds). Inflammation and repair: in Robbins Pathologic Basis of Disease. Philadelphia: WB Saunders Company, 1994. P. 51-93. 
12. Irún P., Alfonso P., Aznarez S., Giraldo P., Pocovi M. Chitotriosidase variants in patients with Gaucher disease. Implications for diagnosis and therapeutic monitoring. Clin. Biochem. 2013; 46(18): 1804-1807.

13. Da Silva-José T. D., Juárez-Rendón K. J., JuárezOsuna J. A., Porras-Dorantes A., ValladaresSalgado A., Cruz M., Gonzalez-Ibarra M., Soto A. G., Magaña-Torres M. T., SandovalRamírez L., García-Ortiz J.E. Dup-24 bp in the CHIT1 Gene in Six Mexican Amerindian Populations. JIMD Rep. 2015; 23: 123-127.

14. Manno N., Sherratt S., Boaretto F., Coico F. M., Camus C. E., Campos C. J., Musumeci S., Battisti A., Quinnell R. J., León J. M., Vazza G., Mostacciuolo M. L., Paoletti M. G., Falcone F. H. High prevalence of chitotriosidase deficiency in Peruvian Amerindians exposed to chitinbearing food and enteroparasites. Carbohydr. Polym. 2014; 113: 607-614.

15. Woo K. H., Lee B. H., Heo S. H., Kim J. M., Kim G. H., Kim Y. M., Kim J. H., Choi I.H., Yang S. H., Yoo H. W. Allele frequency of a 24 bp duplication in exon 10 of the CHIT1 gene in the general Korean population and in Korean patients with Gaucher disease. J. Hum. Genet. 2014; 59(5): 276-279.
16. Piras I., Melis A., Ghiani M. E., Falchi A., Luiselli D., Moral P., Varesi L., Calò C. M., Vona G. Human CHIT1 gene distribution: new data from Mediterranean and European populations. J. Hum. Genet. 2007; 52(2): 110116.

17. Rodrigues M. D., Muller K. B., Pereira V. G., Martins A. M., D'Almeida V. Chitotriosidase deficiency in Brazil: evaluation of enzyme activity and genotypes. Blood Cells Mol. Dis. 2010; 44(4): 305-306.

18. Duarte A. J., Ribeiro D., Amaral O. CHIT1 genetic defects in the Portuguese population. Blood Cells Mol. Dis. 2013; 50(1): 50-52.

19. van Dussen L., Hendriks E. J., Groener J. E., Boot R. G., Hollak C. E., Aerts J. M. Value of plasma chitotriosidase to assess nonneuronopathic Gaucher disease severity and progression in the era of enzyme replacement therapy. J. Inherit. Metab. Dis. 2014; 37(6): 9911001.

20. Rodrigues M. R., Sá Miranda M. C., Amaral O. Allelic frequency determination of the 24-bp chitotriosidase duplication in the Portuguese population by real-time PCR. Blood Cells Mol. Dis. 2004; 33(3): 362-364. 